\title{
PENGARUH KEFASIHAN MEMBACA AL-QUR'AN TERHADAP KETERAMPILAN MEMBACA PADA BIDANG STUDI BAHASA ARAB
}

\author{
Junaidi \\ Universitas Nahdlatul Ulama NTB \\ Corresponding Author: junaidiqorny86@gmail.com \\ Baiq. Mulianah \\ Universitas Nahdlatul Ulama NTB \\ baiqmulianah@unu-ntb.ac.id
}

Article History

Submitted: 16 Nov 2020; Revised: 10 Dec 2020; Accepted:19 Dec 2020

DOI: $10.20414 /$ tsaqafah.v19i2.2749

\begin{abstract}
This study aims to determine the effect of fluency in reading al-quran on reading skills in Arabic for Class X MA. Yusuf Abdussatar, Kediri Village, Kediri District, West Lombok. This approach is quantitative research, because the data collected is in the form of numbers. In this study, there are several instruments that researchers use in collecting the required research data, including: (1) Observation guidelines / guides, this can be in the form of columns containing the variables to be observed. (2) Interview guidelines, namely. A collection of questions made as a guide in interviewing respondents. (3) Questionnaire, namely, a data collection tool in the form of written questions addressed to respondents. (4) Documentation, namely, a data collection tool in the form of columns containing the situation and conditions of the research object. The data analysis used is the Causal Comprativ study, which is used to explain the correlation or relationship between two variables. The conclusion from the results of this study is that there is an effect of reading fluency in the Qur'an on reading skills in the field of study in Arabic for Class X MA. Yusuf Abdussatar Kediri, West Lombok, 2019-2020 Academic Year. This is evidenced by the number that the researcher got after conducting the research with the results obtained by rcount is (0.041) while the $r$ table tested at a significant level of $5 \%$ with the total population $(\mathrm{N})=20$ is 0,012 . This fact shows that rcount is greater than $r$ table $(0.014>0.012)$ thus the correlation value obtained from this study is significant.
\end{abstract}

Key words: fluency in reading Al-quran, skills in reading Arabic 


\begin{abstract}
Abstrak: Tujuan penelitian ini adalah untuk mengetahui pengaruh kefasihan membaca al-qur'an terhadap keterampilan membaca pada bidang studi bahasa arab Kelas X MA. Yusuf Abdussatar Desa Kediri Kecamatan Kediri Lombok Barat. Pendekatan ini adalah penelitian kuantitatif, karena data yang dikumpulkan berupa angka-angka. Dalam penelitian ini ada beberapa instrumen yang peneliti gunakan dalam pengumpulan data penelitian yang dibutuhkan, diantaranya: (1) Pedoman/ panduan observasi, ini bisa berupa kolom-kolom yang berisi tentang variabel-variabel yang akan diamati. (2) Pedoman wawancara yaitu. Suatu kumpulan pertanyaan yang dibuat sebagai pedoman dalam mewawancarai responden. (3) Angket yaitu, suatu alat pengumpul data yang berbentuk pertanyaan-pertanyaan tertulis yang ditujukan kepada responden. (4) Dokumentasi yaitu, suatu alat pengumpulan data yang berupa kolom-kolom yang berisi tentang situasi dan kondisi dari obyek penelitian. Analisis data yang digunakan adalah Causal Comprativ study yaitu digunakan untuk menerangkan korelasi atau hubungan antara dua variabel. Adapun kesimpulan dari hasil penelitian ini adalah Ada Pengaruh Kefasihan Membaca Al-Qur'an Terhadap Keterampilan Membaca Bidang Studi Bahasa Arab Kelas X MA. Yusuf Abdussatar Kediri Lombok Barat Tahun Pelajaran 2019-2020. Hal ini terbukti dengan angka yang peneliti daptkan setelah melakukan penelitian dengan hasil diperoleh $\mathrm{r}_{\text {hitung }}$ adalah $(0,041)$ sedangkan $r_{\text {tabel }}$ yang di uji pada taraf signifikan $5 \%$ dengan jumlah populasi $(\mathrm{N})=20$ adalah 0,012 . Kenyataan ini menunjukkan bahwa $\mathrm{r}_{\text {hitung }}$ lebih besar dari $\mathrm{r}_{\text {tabel }}(0,014>0,012)$ dengan demikian nilai korelasi yang diperoleh dari penelitian ini adalah signifikan.
\end{abstract}

Kata-kata kunci: Kefasihan Membaca Al-qur'an, Keterampilam Membaca Bahasa Arab

\title{
A. Pendahuluan
}

Bahasa Arab merupakan bidang studi yang sangat penting di dalam lingkungan Madrasah, baik di sekolah negeri maupun di swasta. Pada dasarnya pelajaran bahasa Arab di Madrasah Aliyah adalah salah satu bagian dari kurikulum yang diarahkan untuk mendorong, membimbing, mengembangkan, dan membina kemampuan berbahasa arab baik secara aktif maupun pasif.

Pelajaran bahasa Arab yang diajarkan di Madrasah berfungsi sebagai bahasa agama di samping sebagai alat komunikasi. Bahasa memegang peranan penting dalam kehidupan kita. Oleh karena itu, pelajaran bahasa Arab di Madrasah Aliyah merupakan mata pelajaran yang tidak dapat terpisahkan dari mata pelajaran AlQur'an dan Hadits sebagai suatu keseluruhan.

Untuk mencapai keterampilan membaca pada bidang studi bahasa arab, maka diperlukan kefasihan membaca Al-Qu'ran. Salah satu faktor yang penting dalam menunjang tercapainya tujuan pendidikan dan pengajaran bahasa Arab adalah penguasaan metode yang efektif, dan meningkatkan kompetensi kepribadian guru 
dikehendaki pengembangan kompetensi kepribadian guru harus ditingkatkan dan dilakukan secara terus menerus melalui diklat, lanjutan pendidikan formal, dan bimbingan teman sejawat sehingga proses pencapaian tujuan dapat dicapai dengan memuaskan ${ }^{1}$.

Lembaga pendidikan formal maupun non formal tentu harus mempunyai komponen yang dapat membantu dan mempengaruhi proses belajar dan mengajar seperti metode mengajar. Relasi guru dengan siswa, relasi siswa dengan siswa, disiplin sekolah, standar pelajaran, keadaan gedung, metode belajar dan tugas rumah. Komponen-komponen tersebut dapat mendukung dan meningkatkan belajar siswa. Madrasah Aliyah Yusuf Abdussatar Desa Kediri Kecamatan Kediri Lombok Barat, mempunyai siswa dan siswi dengan latar belakang pendidikan yang berbeda yakni berasal dari Madrasah Tsanawiah dan Sekolah Menengah Pertama, perbedaan latar belakang inilah yang menyebabkan guru harus memiliki kemampuan dalam mengkombinasikan beberapa metode kemudian diterapkan sesuai dengan situasi dan kondisi di Madrasah tersebut ${ }^{2}$

Pada dasarnya, untuk mempelajari bahasa arab pada tingkat Madrasah Aliyah khususnya kelas X yang terdiri dari peserta didik yang mempunyai latar belakang yang berbeda, seharusnya yang diutamakan adalah bagaimana cara berbahasa arab yang baik dan benar, bukan teori-teori bahasa atau tata bahasa itu sendiri, karena mempelajari tata bahasa bukan tujuan dari pembelajaran bahasa, melainkan suatu sarana untuk dapat menggunakan bahasa yang benar dalam berkomunikasi. Oleh karena itu, di Madrasah Aliyah Yusuf Abdussatar Desa Kediri Kecamatan Kediri Lombok Barat menerapkan kefasihan membaca Al-Qur'an yang bertujuan untuk meningkatkan keterampilan membaca siswa pada bidang studi bahasa arab.

Kefasihan membaca al-Qur'an adalah mempelajari bacaan al-Qur'an dengan cara tartil yaitu membaca dengan cara memperhatikan sifat-sifat huruf dan tajwidnya ${ }^{3}$. Adapun pengaruh kefasihan membaca al-Qur'an terhadap keterampilan membaca pada bidang studi bahasa Arab yaitu dengan kefasihan membaca al-Qur'an siswa mampu membaca bidang studi bahasa Arab secara baik dan benar.

Dalam teori membaca dikenal beberapa strategi membaca. Pada dasarnya, strategi membaca menggambarkan bagaimana pembaca memproses bacaan sehingga dia memperoleh pemahaman terhadap bacaan tersebut Dengan uraian latar belakang diatas peneliti ingin mengkaji dan mengangkat judul penelitian yaitu "Pengaruh Kefasihan Membaca Al-Qur'an Terhadap Keterampilan Membaca Pada Bidang Studi Bahasa Arab Kelas X MA. Yusuf Abdussatar Desa Kediri Kecamatan Kediri Lombok Barat".

1 Kompetensi Kepribadian, Kompetensi Sosial Guru dan Prestasi Belajar Siswa di Kabupaten Tanah Laut, Penerbit : Pustaka Banua, tahun 2014, h. 37

2 Jaelani, Guru bidang Studi Bahasa arab MA Yusuf Abdussatar (Wawancara: Tgl, 10 maret 2020)

3 Mudawi Ma’arif Tahsin Al-Qur'an (Al-Qashwa: 2009),h. 1 


\section{B. Landasan Teori}

\section{Kefasihan Membaca Al-Qur'an}

a. Pengertian Kefasihan Membaca Al-Qur'an

Dalam kamus besar Bahasa Indonesia kefasihan membaca adalah keadaan lancarnya sesuatu yang tidak terputus-putus, tersendat-sendat (fasih) ${ }^{4}$.

Al-Qur'an adalah firman Allah yang diturunkan kepada Nabi Muhammad SAW melalui malaikat Jibril yang merupakan mukjizat terbesar sepanjang sejarah manusia ${ }^{5}$. Jadi kefasihan membaca al-Qur'an adalah mempelajari bacaan al-Qur'an dengan cara tartil yaitu membaca dengan cara memperhatikan sifat-sifat huruf dan tajwidnya.

Kefasihan yang dimaksud dalam tulisan ini adalah mempelajari bacaan alQur'an dengan benar dan baik sehingga bacaan al-Qur'an kita menjadi tartil ${ }^{6}$. Dengan kefasihan membaca al-Qur'an siswa diharapkan mampu membaca bidang studi bahasa Arab dengan baik dan benar. Sebagaimana perintah Allah dalam surah Al-Muzammil ayat 4:

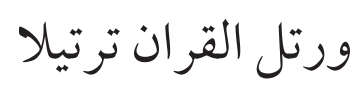

“.., dan bacalah al-Qur'an itu dengan perlahan-lahan

b. Langkah-langkah membaca al-Qur'an dengan fasih

1. Mengenal huruf hijaiyah

Langkah pertama agar fasih dan lancar membaca al-Qur'an dengan baik dan benar adalah dengan mengenal bentuk huruf hijaiyah terlebih dahulu. Tanpa mengenal huruf hijaiyah, kita akan mengalami kesulitan, bahkan tidak akan mampu membaca al-Qur'an. Huruf hijaiyah adalah kumpulan huruf-huruf Arab yang berjumlah $29^{7}$.

2. Mengetahui kaidah dan hukum bacaan

Dalam hal ini dibagi menjadi dua macam yaitu Makhorijul huruf dan hukum Tajwid.

a. Makhorijul Huruf yaitu tempat keluarnya huruf hijaiyah mulai dari huruf Alif sampai huruf Ya.

4 Kamus Besar Bahasa Indonesia Edisi Ketiga (Jakarta: Balai Pustaka 2002). h.633

5 Laboratorium Al-qur'an IAIN Mataram Pintu Cahaya Al-qur'an (Lembaga Bahasa dan Budaya IAIN Mataram 2010). h. 1

6 Mudawi Ma’arif. Tahsin Al-Qur'an. (Bumi Suko Indah Siduardjo Al-Qashwa. 2009)

7 Amirulloh Syarbini \& Abu Mufidah al-Kautsar. 5 Langkah Lancar Membaca al-Qur'an (Bandung: Ruang Kata 2010).h.2 
b. Hukum Tajwid dibahas melalui kajian kaidah tajwid yang terdapat dalam 12 surah al-Qur'an yaitu surah al-Fatihah sampai surah al-Humazah ${ }^{8}$.

3. Memahami tanda Waqaf

Waqaf adalah memutuskan suara pada suatu kalimat dalam waktu tertentu, tidak begitu lama, kemudian mengambil napas satu kali dengan niat memulai kembali bacaan al-Qur'an. Waqaf bertujuan mewujudkan bacaan al-Qur'an dengan tartil. Jadi, seseorang belum dikatakan tartil membaca al-Qur'an, jika tidak memperhatikan hukum bacaan waqaf?.

\section{Konsep Dasar Keterampilan Membaca pada Bidang Studi bahasa Arab}

a. Pengertian Keterampilan Membaca

Dalam kamus besar Bahasa Indonesia keterampilan adalah kecakapan untuk menyelesaikan tugas ${ }^{10}$. Membaca adalah meyuarakan huruf-huruf atau deretan huruf yang berupa kata atau kalimat ${ }^{11}$. Membaca merupakan awal dari setiap pembelajaran bahasa. Dengan membaca siswa dilatih berbicara, bercerita, dan mampu mengungkapkan pendapat juga membuat kesimpulan. Berdasarkan pengertian keterampilan dan membaca dapat disimpulkan bahwa keterampilan membaca adalah kemampuan yang harus dimiliki oleh setiap siswa untuk menyelesaikan tugas-tugas yang berupa tulisan maupun teks.

b. Karakteristik Kemampuan Mambaca Bahasa Arab

Adapun ciri-ciri atau karakteristik kemampuan Bahasa Arab ada lima, yaitu:

1. Tujuan utamanya adalah kemahiran membaca, yaitu agar pelajar mampu memahami teks ilmiah untuk keperluan studi mereka.

2. Materi pelajaran berupa buku bacaan utama dengan suplemen daftar kosa kata dan pertanyaan-pertanyaan isi bacaan, buku bacaan penunjang untuk perluasan (extensive reading/قراءة موسعة), buku latihan mengarang terbimbing dan percakapan.

3. Basis kegiatan pembelajaran adalah memahami isi bacaan, didahului oleh pengenalan kosa kata pokok dan maknanya, kemudian mendiskusikan isi bacaan dengan bantuan guru.

4. Membaca diam (silent reading/قراءة صامتة (قراءة جهرية) lebih diutamakan dari pada membaca keras (loud reading/ قراءة جهرية )

5. Kaidah bahasa diterangkan seperlunya tidak boleh berkepanjangan ${ }^{12}$.
8 Ibid,h.5
9 Ibid,h.58
10 Kamus Besar Bahasa Indobesia, Edisi ke 3. h. 1180
11 Nenden Kiat Membaca Anak Gemar Membaca (Surabaya: Al-Maktabah, 2008). h. 3
12 Ibid, h. 41-42 
Jadi dari karaktiristik Bahasa arab di atas siswa diharapkan mahir membaca dan mampu memahami teks ilmiah untuk keperluan studi mereka dan siswa juga diharapkan mampu memahami isi bacaan yang didahului oleh pengenalan kosa kata pokok dan maknanya kemudian siswa mendiskusikan isi bacaan dengan bantuan guru.

\section{Metode Penelitian}

\section{Desain dan Pendekatan Penelitian}

Sesuai masalah yang akan dikaji dalam artikel ini serta memperhatikan jenis kajian dan macam data yang akan dikumpulkan, maka peneliti akan menggunakan pendekatan kuantitatif. Karena data atau informasi yang penulis kumpulkan dalam penelitian ini berbentuk kuantitatif yang memerlukan perhitungan dengan menggunakan angka-angka statistik dalam proses analisa data.

Data-data yang diperoleh dilapangan berupa angka-angka akan diperoleh dengan cara menghimpun, mengatur, menyusun, mengelola, menganalisa, menyajikan, kemudian setelah melalui proses diatas, barulah dapat ditarik kesimpulan.

Pendekatan kuantitatif adalah suatu proses menemukan pengetahuan yang menggunakan data berupa angka sebagai alat. Menurut sifatnya, penelitian ini termasuk penelitian kolerasional, yaitu melihat sejauh mana keterkaitan atau hubungan antara dua variable atau lebih berdasarkan koefisien kolerasinya. Karena itu dalam melaksanakan penelitian ini digunakan pendekatan kuantitatif ${ }^{13}$.

Dalam hal ini, peneliti menggunakan metode penelitian yang bercorak kuantitatif, karena peneliti ingin meneliti apakah ada pengaruh kefasihan membaca Al-Qur'an terhadap keterampilan membaca pada bidang studi bahasa Arab kelas X MA. Yusuf Abdussatar Desa Kediri Kecamatan Kediri Lombok Barat Tahun Pelajaran 2019-2020

\section{Populasi dan Teknik Sampling}

\section{a. Populasi}

Setiap penelitian ilmiah selalu berhadapan dengan subyek dan obyek yang diteliti yang selanjutnya dapat dijadikan populasi dan sampel penelitian. Populasi adalah keseluruhan subjek penelitian ${ }^{14}$. Sedangkan menurut pendapat lain populasi adalah: generalisasi yang terdiri atas obyek dan subyek yang mempunyai kualitas dan karakteristik tertentu yang ditetapkan oleh peneliti untuk dipelajari dan kemudian ditarik kesimpulannya ${ }^{15}$.

13 Suharsimi Arikunto, prosedur Penelitian Suatu Pendekatan Praktik Edisi Revisi VI (Jakarta: PT, Rineka Cipta, 2006), h. 82.

14 Suharsimi Arikunto, Prosedur Penelitian Suatu Pendekatan Praktik Edisi Revisi VI (Jakarta: PT. Rineka Cipta, 2006), h. 130. 2007),h. 81

15 Sugiyono Metode Penelitian Kuantitatif Kualitatif dan R\&D (Bandung: Penerbit Alfabeta, 
Populasi dalam hal ini adalah seluruh siswa kelas X MA. Yusuf Abdussatar Desa Kediri Kecamatan Kediri Lombok Barat Tahun Pelajaran 2019-2020 yang berjumlah 77 orang. Apabila seorang ingin meneliti semua elemen yang ada diwilayah penelitian, maka disebut penelitian populasi. Studi atau penelitiannya juga disebut studi populasi atau setudi sensus. Apabila subjeknya kurang dari 100, maka diambil semua sehingga penelitiannya merupakan penelitian populasi. Selanjutnya apabila subyeknya lebih dari 100 dapat diambil 10-15 atau lebih.

\section{b. Teknik Sampling}

Tekning sampling adalah "merupakan teknik pengambilan sampel"16. Adapun teknik pengambilan sampling dalam penelitian ini menggunakan teknik random sampling. Random sampling adalah "suatu teknik penentuan sampling dimana semua populasi mempunyai kesempatan yang sama untuk dipilih menjadi anggota sampel” adalah kelas X MA dimana jumlah mereka kurang dari 100 orang, yaitu 77 orang siswa. ini berarti tidak ada kegiatan pengambilan sampel yang akan dilakukan karena seluruh siswa kelas X MA akan menjadi responden. Dengan begitu maka penelitian ini merupakan penelitian populasi yang mana semua populasinya menjadi subyek penelitian.

\section{Instrumen Penelitian}

Instrumen merupakan alat ukur yang dipergunakan untuk mendapatkan informasi kuantitatif tentang variasi karakteristik variable secara objektif ${ }^{17}$. Penelitian adalah alat atau fasilitas ynag digunakan untuk mengumpulkan data agar pekerjaannya lebih mudah dan hasilnya lebih baik, dalam arti lebih cermat, lengkap dan sistematis sehingga mudah diolah ${ }^{18}$.

Adapun alat-alat atau instrumen yang digunakan adalah sebagai berikut:

a. Pedoman/ panduan observasi, ini bisa berupa kolom-kolom yang berisi tentang variabel-variabel yang akan diamati.

b. Pedoman wawancara yaitu. Suatu kumpulan pertanyaan yang dibuat sebagai pedoman dalam mewawancarai responden.

c. Angket yaitu, suatu alat pengumpul data yang berbentuk pertanyaanpertanyaan tertulis yang ditujukan kepada responden.

d. Dokumentasi yaitu, suatu alat pengumpulan data yang berupa kolomkolom yang berisi tentang situasi dan kondisi dari obyek penelitian

16 Sugiyono. Statistik Penelitian (Jakarta: Rineka Cipta, 2003), h. 56

17 Ibnu Hajar, Dasar-dasar Metodologi Penelitian Kuantitatif Dalam Pendidikan (Jakarta: PT. Grafindo Persada, 1996), h. 160

18 Arikunto Prosedur Penelitian.(Jakarta: Rineka Cipta, 2006),h. 219 


\section{Teknik Pengumpulan Data}

Dalam memperoleh data yang dibutuhkan dan diperlukan teknik atau metode pengumpulan data, sehingga data yang diperoleh dapat dipertanggung jawabkan secara ilmiah. Teknik pengumpulan data yang diperlukan dalam penelitian adalah tes, wawancara, observasi, dan dokumentasi.

\section{Teknik Analisis Data}

Setelah data terkumpul, maka langkah selanjutnya adalah mengolah dengan menganalisis data. Analisis data adalah proses penyederhanaan data dalam bentuk yang lebih mudah dibaca dan diinterprestasikan selanjutnya untuk menarik kesimpulan. Adapun jenis analisa korelasi a). Analisis komparasi b). Analisis korelasi causal conparative studi c). Analisis koefisien korelasi. ${ }^{19}$ Sedangkan analisis yang dipakai dalam penelitian ini adalah: Causal Comprativ study yaitu digunakan untuk menerangkan korelasi atau hubungan antara dua variabel.

Dalam penelitian ini data-data yang peneliti akan peroleh di lapangan bersifat kuantitatif, maka dalam menganalisisnya tentu menggunakan pendekatan statistik. Melalui cara ini akan ditemukan adanya pengaruh kefasihan membaca Al-qur'an terhadap keterampilan membaca pada bidang studi bahasa arab kelas X MA. Yusuf Abdussatar Desa Kediri Kecamatan Kediri Lombok Barat Tahun Pelajaran 20192020.

Karena data yang diperoleh melalui instrumen penelitian masih berupa data mentah. Maka untuk menganalisis data tersebut peneliti menggunakan analisis statistik dengan menggunakan rumus korelasi product moment (angka kasar) yaitu sebagai berikut :

$\mathrm{rxy}=\frac{N \sum X-\left(\sum X\right)\left(\sum Y\right)}{\sqrt{\left\{\sum X^{2}-\left(\sum X\right)^{2}\right.}}$

Keterangan:

rxy $=$ Koefisien korelasi produc moment

$\mathrm{XY}=$ Jumlah hasil X dan $\mathrm{Y}$

$\mathrm{X}=$ Angka variabel $\mathrm{X}$

$\mathrm{Y} \quad=$ Angka variabel $\mathrm{Y}$

$\mathrm{N} \quad=$ Jumlah individu yang diselidiki ${ }^{20}$.

\section{Hasil Penelitian dan Pembahasan}

\section{Penyajian Data}

Data yang disajikan dalam penelitian ini yang diperoleh dari tempat dilaksanakan penelitian yaitu: data tentang Pengaruh Kefasihan Membaca Al-Qur'an terhadap

19 Arikunto, Prosedur Penelitian (Jakarta: PT. Rineka Cipta, 2006), h. 251

20 Hartono Statistik Untuk Penelitian (Jogjakarta: Pustaka Pelajar, 2004) h. 76 
Keterampilan Membaca Pada Bidang Studi bahasa Arab MA Kelas X Yusuf Abdussatar Kediri Lombok Barat Tahun Pelajaran 2019-2020.

Sebelum data disajikan, terlebih dahulu peneliti menjelaskan variabel-variabel dalam penelitian ini yaitu kefasihan membaca Al-Qur'an merupakan variabel bebas $(\mathrm{X})$ hasilnya diperoleh dari tes lisan membaca Al-qur'an dan sebagai variabel terikatnya (Y) hasilnya diperoleh dari tes lisan dan tulisan. Adapun data-data dan nilai sebagai berikut: ${ }^{21}$

Tabel 1

Daftar Hasil Tes Kefasihan Membaca Al-Qur’an

\begin{tabular}{|c|c|c|c|}
\hline No & Nama Siswa & Nilai & Ket \\
\hline 1 & Habib Akmal Algivari & 55 & \\
\hline 2 & Muhammad Asdullah & 60 & \\
\hline 3 & Amrullah & 60 & \\
\hline 4 & Irzan Nurholis & 55 & \\
\hline 5 & Abdul Majid & 60 & \\
\hline 6 & Rifki Maulana & 50 & \\
\hline 7 & Ahmad nasri & 55 & \\
\hline 8 & Abdul manan & 50 & \\
\hline 9 & Lukmanul Hakim & 60 & \\
\hline 10 & Muhammad sulpi junaidi & 57 & \\
\hline 11 & M. ridho saputra & 59 & \\
\hline 12 & M. Sahrullah & 55 & \\
\hline 13 & M. Uzaini & 58 & \\
\hline 14 & $\begin{array}{l}\text { Muhammad Ar-Rahmanu } \\
\text { Wafda }\end{array}$ & 65 & \\
\hline 15 & Muhammad hamdani & 60 & \\
\hline 16 & Abdul halim & 59 & \\
\hline 17 & L. Muhammad Abdul Majid & 55 & \\
\hline 18 & Sulhan & 60 & \\
\hline 19 & M. Roni Aprizal & 57 & \\
\hline 20 & Nasri & 60 & \\
\hline \multicolumn{2}{|c|}{ Jumlah } & 1150 & \\
\hline
\end{tabular}

21 Hasil tes kelancaran membaaca Al-qur'an dan keterampilan membaca teks bidang studi bahasa Arab. 21 Juli 2020 
Tabel 2

\section{Daftar Hasil Tes Keterampilan Membaca Bidang Studi Bahasa Arab}

\begin{tabular}{|c|c|c|c|}
\hline No & Nama Siswa & Nilai & Ket \\
\hline 1 & Habib Akmal Algivari & 65 & \\
\hline 2 & Muhammad Asdullah & 60 & \\
\hline 3 & Amrullah & 70 & \\
\hline 4 & Irzan Nurholis & 65 & \\
\hline 5 & Abdul Majid & 75 & \\
\hline 6 & Rifki Maulana & 60 & \\
\hline 7 & Ahmad nasri & 55 & \\
\hline 8 & Abdul manan & 75 & \\
\hline 9 & Lukmanul Hakim & 60 & \\
\hline 10 & Muhammad sulpi junaidi & 50 & \\
\hline 11 & M. ridho saputra & 55 & \\
\hline 12 & M. Sahrullah & 70 & \\
\hline 13 & M. Uzaini & 60 & \\
\hline 14 & $\begin{array}{l}\text { Muhammad Ar-Rahmanu } \\
\text { Wafda }\end{array}$ & 55 & \\
\hline 15 & Muhammad hamdani & 65 & \\
\hline 16 & Abdul halim & 60 & \\
\hline 17 & L. Muhammad Abdul Majid & 70 & \\
\hline 18 & Sulhan & 50 & \\
\hline 19 & M. Roni Aprizal & 65 & \\
\hline 20 & Nasri & 60 & \\
\hline \multicolumn{2}{|c|}{ Jumlah } & 1245 & \\
\hline
\end{tabular}

\section{Analisis Data}

Setelah data terkumpul maka langkah selanjutnya mengadakan analisis data. Jenis analisis data yang peneliti gunakan yaitu analisis data dengan pendekatan kuantitatif dengan menggunakan rumus korelasi product moment. Dan yang menjadi subyek dalam penelitian ini adalah 20 orang siswa yang diambil dari sebagaian siswa kelas $\mathrm{X}$ MA. Yusuf Abdussatar Kediri Lombok Barat Tahun Pelajaran 2019-2020.

Langkah-langkah dalam mengalisis data hasil penelitian sebagai berikut:

1. Merumuskan Hipotesis

Dilihat dari perumusannya, hipotesis dibedakan menjadi dua yaitu ${ }^{22}$ :

a. Hipotesis Alternatif $\left(\mathrm{H}_{1}\right)$ yang rumusnya dinyatakan dalam kalimat positif. 
$\mathrm{H}_{1}$ :"Ada Pengaruh Kefasihan Membaca Al-Qur'an Terhadap Keterampilan Membaca Bidang Studi Bahasa Arab Kelas X MA. Yusuf Abdussatar Kediri Lombok Barat Tahun Pelajaran 2019-2020".

2. Hipotesis $\mathrm{Nol}\left(\mathrm{H}_{\mathrm{O}}\right)$ yang rumusnya dinyatakan dalam kalimat negatif.

$-{ }^{\star} \mathrm{H}_{\mathrm{O}}$ : 'Tidak Ada Pengaruh Kefasihan Membaca Al-Qur'an Terhadap Keterampilan Membaca Bidang Studi Bahasa Arab Kelas X MA. Yusuf Abdussatar Kediri Lombok Barat Tahun Pelajaran 2019-2020"

Ketentuan kaedahnya:

Jika $\mathrm{r}_{\text {hitung }}>\mathrm{r}_{\text {tabel }}$ maka $\mathrm{H}_{1}$ diterima dan $\mathrm{H}_{\mathrm{O}}$ ditolak. Tetapi di uji $\mathrm{r}_{\text {hitung }}<\mathrm{r}_{\text {tabel }}$ maka $\mathrm{H}_{\mathrm{o}}$ diterima dan $\mathrm{H}_{1}$ ditolak.

Dari kedua hipotesis di atas, maka yang akan di uji oleh peneliti yaitu hipotesis $\mathrm{H}_{1}$ yang berbunyi: "Ada Pengaruh Kefasihan Membaca Al-Qur'an Terhadap Keterampilan Membaca Bidang Studi Bahasa Arab Kelas X MA. Yusuf Abdussatar Kediri Lombok Barat Tahun Pelajaran 2019-2020”.

3. Menyusun Tabel Kerja

Setelah merumuskan hipotesis maka langkah selanjutnya menyusun tabel kerja hasil penelitian tentang Pengaruh Kefasihan Al-Qur'an Terhadap Kefasihan Membaca Pada Bidang Studi Bahasa Arab Kelas X MA. Yusuf Abdussatar Kediri Lombok Barat Tahun Pelajaran 2019-2020, dapat dilihat pada tabel berikut ini.

Tabel 3

Tabel Kerja Korelasi r (Product Moment)

\begin{tabular}{cccccc}
\hline No & $\mathbf{X}$ & $\mathbf{Y}$ & $\mathbf{Y}^{2}$ & $\mathbf{Y}^{2}$ & $\mathbf{X y}$ \\
\hline 1 & 55 & 65 & 3025 & 4225 & 3575 \\
\hline 2 & 60 & 60 & 3600 & 3600 & 3600 \\
\hline 3 & 60 & 70 & 3600 & 4900 & 4200 \\
\hline 4 & 55 & 65 & 3025 & 4225 & 3575 \\
\hline 5 & 60 & 75 & 3600 & 5625 & 4500 \\
\hline 6 & 50 & 60 & 2500 & 3600 & 3000 \\
\hline 7 & 55 & 55 & 3025 & 3025 & 3025 \\
\hline 8 & 50 & 75 & 2500 & 5625 & 3750 \\
\hline 9 & 60 & 60 & 3600 & 3600 & 3600 \\
\hline 10 & 57 & 50 & 3249 & 3025 & 2850 \\
\hline 11 & 59 & 55 & 3481 & 3025 & 3245 \\
\hline 12 & 55 & 70 & 3025 & 4900 & 3850 \\
\hline 13 & 58 & 60 & 3364 & 3600 & 3480 \\
\hline 14 & 65 & 55 & 4265 & 3025 & 3575 \\
\hline 15 & 60 & 65 & 3600 & 4225 & 3900 \\
\hline
\end{tabular}


El-Tsaqafah: Jurnal Jurusan PBA, Vol. 19, No.2, 2020

\begin{tabular}{cccccc}
\hline 16 & 59 & 60 & 3481 & 3600 & 3540 \\
\hline 17 & 55 & 70 & 3025 & 4900 & 3850 \\
\hline 18 & 60 & 50 & 3600 & 3025 & 3000 \\
\hline 19 & 57 & 65 & 3249 & 4225 & 3705 \\
\hline 20 & 60 & 60 & 3600 & 3600 & 3600 \\
\hline$\sum$ & 1150 & 1245 & 66414 & 79575 & 71420 \\
\hline
\end{tabular}

Dari tabel di atas diketahui bahwa:

$$
\begin{aligned}
& \mathrm{N}=20 \\
& \sum x=1150 \\
& \sum y=1245 \\
& \sum x^{2}=66414 \\
& \sum y^{2}=79575 \\
& \sum x=71420
\end{aligned}
$$

4. Memasukkan Angka Dalam Rumus

Nilai yang diperoleh di tabel 05 akan dimasukkan ke dalam rumus korelasi product moment sebagai berikut:

$$
\begin{aligned}
& \operatorname{rxy}=\frac{n \sum x-\left(\sum x\right)\left(\sum y\right)}{\sqrt{\left\{\sum x^{2}-\left(\sum x\right)^{2}\right)\left(\sum y^{2}-\left(\sum y\right)^{2}\right.}} \\
& =\frac{D \times 71420-(1150 \times 1245)}{\sqrt{\left.\oint \times 66414-(1150)^{2}\right)\left(2 \times 79575-(1245)^{2}\right.}} \\
& =\frac{1428400-1431750}{\sqrt{1328280-1322500 \times 1591500-1550025}} \\
& =\frac{3350}{\sqrt{138608 \times 41475}} \\
& =\frac{3350}{57820, \mathbb{Q}} \\
& =0,041
\end{aligned}
$$

Adapun perhitungan korelasi product moment dengan menggunakan rumus di atas adalah dengan memasukkan skor dari masing-masing variabel. 


\section{Hasil Analisis}

Setelah data diperoleh dan dianalisis maka yang diperlukan dalam sebuah penelitian yaitu hasilanalisis data. Darihasilanalisis perhitungan dengan menggunakan rumus korelasi product moment diperoleh $r_{\text {hitung }}$ adalah $(0,041)$ sedangkan $r_{\text {tabel }}$ yang di uji pada taraf signifikan $5 \%$ dengan jumlah populasi $(\mathrm{N})=20$ adalah 0,012 . Kenyataan ini menunjukkan bahwa $r_{\text {hitung }}$ lebih besar dari $r_{\text {tabel }}(0,014>0,012)$ dengan demikian nilai korelasi yang diperoleh dari penelitian ini adalah signifikan.

Sehingga hipotesis alternatif (H1) yang berbunyi "Ada Pengaruh Kefasihan Membaca Al-Qur'an Terhadap Keterampilan Membaca Bidang Studi Bahasa Arab Kelas X MA. Yusuf Abdussatar Kediri Lombok Barat Tahun Pelajaran 2019-2020” diterima dan hipotesis nol $\left(\mathrm{H}_{\mathrm{O}}\right)$ yang berbunyi "Tidak Ada Pengaruh Kefasihan Membaca Al-Qur'an Terhadap Keterampilan Membaca Bidang Studi Bahasa Arab Kelas X MA. Yusuf Abdussatar Kediri Lombok Barat Tahun Pelajaran 2019-2020” ditolak.

\section{Pengujian Hipotesis}

Dalam penelitian ini hipotesis yang diajukan adalah hipotesis alternatif ( $\mathrm{Hi})$ dan hipotesis tersebut berbunyi:

Hi: "Ada pengaruh kefasihan membaca Al-qur'an terhadap keterampilan membaca pada bidang studi bahasa Arab Kelas X MA Yusuf Abdussatar Kediri Lombok Barat Tahun Pelajaran 2019-2020”

Ho:"Tidak Ada pengaruh Kefasihan Membaca Al-qur'an Terhadap Keterampilan Membaca Pada Bidang Studi Bahasa Arab Kelas X MA Yusuf Abdussatar Kediri Lombok Barat Tahun Pelajaran 2019-2020”

Untuk menguji apakah hipotesis diterima atau tidak maka yang digunakan sebagai pegangan adalah uji $\mathrm{r}$ dengan taraf signifikat $5 \%$ bila rhitung $>$ rtabel maka Hi diterima dan Ho ditolak tetapi sebaliknya bila rhitung < rtabel maka Ho diterima dan Hi ditolak.

Berdasarkan hasil hitungan dengan uji r product moment diperoleh sebesar 0,041 dan $r_{\text {tabel }}$ pada taraf signifikan $5 \%$ dengan $(N)=20$ adalah 0,012 hal ini menunjukkan bahwa rhitung lebih besar dari $r_{\text {tabel }} 0,041>0,012$, dengan demikian nilai korelasi dalam penelitian ini signifikan, sehingga hipotesis Hi yang berbunyi Ada pengaruh kefasihan membaca Al-qur'an terhadap keterampilan membaca pada bidang studi bahasa Arab Kelas X MA Yusuf Abdussatar Kediri Lombok Barat Tahun Pelajaran 2019-2020” diterima dan Ho ditolak.

Dari hasil pengujian hipotesis di atas maka dapat mengetahui adanya hubungan yang signifikan antara variabel X (Kefasihan Membaca Al-qur'an) dan variabel Y (keterampilan membaca Bidang studi bahasa Arab ). Hal ini menunjukkan bahwa kefasihan membaca Al-qur'an sangat mempengaruhi keterampilan membaca bidang 
studi Bahasa Arab Kelas X MA Yusuf Abdussatar Kediri Lombok Barat Tahun Pelajaran 2019-2020.

\section{Pembahasan}

Dalam pembahasan ini sebelumnya dijelaskan bahwa kefasihan membaca Alqur'an adalah mempelajari bacaan Al-qur'an dengan cara memperhatikan sifat-sifat huruf dan tajwidnya. kefasihan membaca Al-qur'an di MA Yusuf Abdussatar sebagai penunjang dalam keterampilan membaca dalam bidang studi bahasa Arab siswa kelas X MA Yusuf Abdussatar. Semenjak kefasihan membaca al-Qur'an tersebut siswa banyak mengalami peningkatan dalam membaca bidang studi bahasa Arab khususnya kemampuan membaca menyimak dan berbicaranya.

Keberhasilan kefasihan membaca Al-qur'an dalam meningkatkan kemampuan membaca bidang studi bahasa Arab siswa kelas X di MA. Yusuf Abdussatar terbukti melalui data statistik dan penelitian penulis lakukan.

Untuk mengetahui pengaruh kefasihan membaca al-Qur'an terhadap Keterampilan membaca bidang studi Bahasa Arab Siswa kelas X MA. Yusuf Abdussatar Kediri Lobar Tahun Pelajaran 2019-2020 peneliti mengemukakan dari tabel hasil penelitian, dimana kefasihan membaca al-Qur'an sebagai variabel bebas (X) dan keterampilan membaca bidang studi bahasa Arab sebagai variabel terikat (Y).

Dalam hal ini peneliti menggunakan rumus yang telah disebutkan pada bab sebelumnya kemudian mengkonsultasikannya dengan tabel harga kritik (r) product moment. Dari hasil penelitian tersebut setelah dikonsultasikan dengan tabel harga kritik ( $r$ ) product moment, untuk $N=20$ pada taraf signifikan $5 \%$ sementara $r$ hitung adalah 0, 012. Kenyataan ini menunjukkan bahwa $r_{\text {hitung }}$ lebih besar dari $\mathrm{r}_{\text {tabel }}(0,014>$ 0,012).

Berdasarkan hasil penelitian yang menerima hipotesis alternatif $\left(\mathrm{H}_{1}\right)$, dan dikonsultasikan dengan taraf signifikan 5\% dapat meningkatkan ketarampilan membaca bahasa Arab siswa kelas X MA. Yusuf Abdussatar. Jika kita ingin mengetahui sejauhmana Pengaruh Kefasihan Membaca al-Qur'an Terhadap Keterampilan Membaca bahasa Arab Siswa Kelas X MA. Yusuf Abdussatar dapat disesuaikan dengan tabel berikut.

\section{Tabel 4}

Pedoman Untuk Memberikan Interpretasi koefesien korelasi

\begin{tabular}{cc}
\hline Interval Koefisien & Tingkat Hubungan \\
\hline $0,00-0,199$ & Sangat Rendah \\
$0,20-0,399$ & Rendah \\
$0,40-0,599$ & Sedang \\
$0,60-0,799$ & Kuat \\
$0,80-1,000$ & Sangat Kuat \\
\hline
\end{tabular}


Berdasarkan tabel interpretasi koefesien tersebut, bila disesuaikan dengan hasi perhitungan yang diperoleh dari korelasi product moment sebesar 0,041 termasuk pada tingkat hubungan sedang. Pengaruh Kefasihan Mambaca al-Qur'an terhadap Keterampilan Membaca Bahasa Arab Siswa kelas X MA. Yusuf Abdussatar Kediri Lobar Tahun Pelajaran 2019-2020 disebabkan oleh penerapan kefasihan membaca al-Qur'an hanya dilaksanakan di dalam kelas tetapi juga dilingkungan asrama dan kesadaran dari siswa itu sendiri untuk mendsiplinkan diri daam dalam menggunakan bahasa sasaran, sehingga komunikasi seharian siswa serta proses belajar mengajar menggunakan bahasa Arab.

Berangkat dari keinginan untuk mencetak generasi-genarasi yang memiliki kemampuan membaca al-Qur'an dan Keterampilan membaca bahasa Arab, maka siswa MA. Yusuf Abdussatar Kediri Lombok Barat menerapkan metode pembelajaran bahasa yang lebih fokus kepada kefasihan berbicara aktif secara intensif.

Seorang guru bahasa Arab harus mempunyai komitmen yang kuat untuk memajukan pengajaran bahasa Arab. Namun seringkali, pembelajaran jarang menerapkan bahasa yang sedang dipelajari karena kurangnya kosa kata bahasa sasaran yang mereka ketahui, oleh karena itu diharapkan kepada guru bidang studi bahasa Arab untuk memperbanyak pemberian kosa kata kepada siswa tentang katakata yang sering mereka pergunakan sehari-hari dan menyarankan siswa untuk menggunakan bahasa Arab pada saat proses belajar mengajar maupun lingkungan asrama sementara kaidah nahwa syaraf diajarkan kemudian, karena siswa terbiasa berbicara atau berkomunikasi dalam bahasa sasaran, karena tujuan dari penerapan kefasihan membaca yaitu pelajar terampil menyimak dan berbicara, dan belajar menguasai bahasa secara fungsional tidak sekedar teoritis, artinya harus bisa dipraktik kebenaran ujarannya. Disertai dengan pengawasan dan pengontrolan dari pihak pendidik untuk memupuk sikap disiplin siswa, dimana siswa dilatih untuk patuh dan taat kepaa peraturan-peraturan yang telah ditetapkan.

Dalam mempelajari bahasa asing, nilai disiplin juga sangat diperlukan seorang pembelajar yang senantiasa mendisiplinkan diri untuk selalu melatih kemampuan berbahasanya memalui penggunaan bahasa sasaran sebagai alat komunikasi, akan lebih mudah dan lebih cepat untuk menguasai bahasa sasaran. Penjelasan tersebut menunjukkan betapa pentingnya faktor lingkungan bahasa dalam menanamkan kemampuan berbicara bahasa Arab, karena lingkungan bahasa merupakan wahana pembelajaran dan pemerolehan bagi siswa.

Dengan demikian penerapan kefasihan membaca al-Qur'an dalam proses belajar mengajar dengan berbagai teknik yang sesuai dan tidak bertentangan dengan karakteristiknya yang ditunjang dengan kompetensi komunikatif guru dan sarana prasarana yang memadai dapat terlaksana denga terarah sehingga tujuan yang telah dirumuskan dapat tercapai dengan baik. 


\section{E. Penutup}

Berdasarkan hasil penelitian tentang Pengaruh Kefasihan Membaca al-Qur'an Terhadap Keterampilan Membaca Pada Bidang Studi Bahasa Arab Kelas X MA. Yusuf Abdussatar Kediri Lombok Barat Tahun Pelajaran 2019-2020, dapat ditarik kesimpulan bahwa ada pengaruh kefasihan membaca al-Qur'an terhadap keterampilan Membaca Pada Bidang Studi Bahasa Arab Kelas X MA Yusuf Abdussatar Kediri Lombok Barat Tahun Pelajaran 2019-2020. Hal ini peneliti temukan berdasarkan hasil analisis data dengan menggunakan rumus korelasi product moment maka nilai yang diperoleh $r_{\text {hitung }}>r_{\text {tabel }} r_{\text {hitung }}$ sebesar $(0,041)$ setelah dikonsultasikan dengan $r_{\text {tabel }}$ pada taraf signifikan 5\% dengan $(N)=20$ diperoleh 0,012 . Hal ini menunjukkan bahwa $\mathrm{r}_{\text {hitung }}>$ $\mathrm{r}_{\text {tabel }}(0,014>0,012)$ dan terdapat hubunagan signifikan. Selain pembuktian dengan angka-angka statistik tersebut bahwa bahwa pada kenyataan siswa mampu membaca menggunakan bahasa Arab.

Dengan demikian penggunaan kefasihan membaca al-Qur'an dan keterampilan membaca bahasa Arab sangat berpengaruh terhadap beberapa pihak. Pertama, Madrasah sebagai tempat pelaksanaan kegiatan belajar mengajar hendaknya menciptakan suasana yang nyaman dan kondusif untuk membantu kefasihan proses belajar mengajar, khususnya dalam pengaruh kefasihan membaca al-Qur'an dan keterampilan membaca bidang studi bahasa Arab yang mana nantinya akan membantu dalam meningkatkan kemampuan berbicara bahasa Arab siswa. Kedua, Para guru bahasa Arab, agar mampu menyesuaikan materi yang akan diajarkan dengan karakteristik kefasihan membaca bahasa Arab dan dapat menyajikan dengan tepat dan menarik agar tujuan pembelajaran yang diharapkan dapat tercapai semaksimal mungkin karena guru sebagai pendidik ataupun mengajar merupakan faktor penentu kesukseskan setiap usaha pendidikan. Ketiga, Siswa harus menanamkan sikap disiplin dan kesadaran dari diri sendiri dalam mempelajari bahasa Arab serta menggunakan sebagai alat komunikasi, sehingga dapat meningkatkan kemampuan membaca bahasa Arab yang dimilikinya. Keempat, Bagian perpustakaan hendaknya memperbanyak jumlah buku yang berbahasa Arab. Dengan demikian diharapkan mampu menjadi kontribusi kepada siswa dalam meningkatkan kemampuan membaca yang dimiliki. 


\section{Daftar Pustaka}

Ahmad Fuad Effendy. Metodologi Pengajaran Bahasa Arab. Malang: Misykat. 2005

Arikunto, Prosedur Penelitian. Jakarta: PT. Rineka Cipta. 2006

Arikunto. Suharsimi. Prosedur Penelitian Suatu Pendekatan Praktek. Jakarta: Renika Cipta. 1998.

Farida Rahim, M.Ed. Pengajaran Membaca di Sekolah Dasar. Bumi Aksara. 2008.

Guntur. Menyimak Sebagai Suatu Keterampilan Berbahasa. Bandung: Angkasa. 1987.

Henry Guntur Tarigan. Kompetensi Bahasa. Bandung: Angkasa.2009.

Mudawi Ma'arif. Tahsin Al-Qur'an (Cara Mudah Belajar Tahsin Al-Qur'an Secara Tartil). Sidoardjo: Bumi Suko Indah. Al-Qashwa.

Nenden. Kiat Membuat Anak Gemar Membaca. Surabaya: CV. Al-Maktabah. 2008.

Nurhadi. Membaca Cepat dan Efektif. Bandung: CV. Sinar Baru. 1987

Oemar Hamalik. Proses Belajar Mengajar. Bandung: Bumi Aksara II. 2001.

Pintu Cahaya Al-Qur'an (Dasar-dasar Pengajaran Tajwid Al-Qur'an). Laboratorium AlQur'an IAIN Mataram.

Sugiyono. Metode Penelitian Kuantitatif Kualitatif dan R \& D. Bandung: Alfabeta.2007

Yusuf Tayar dan Saiful Bahri Anwar. Metodologi Pengajaran Agama dan Bahasa Arab. Jakarta: Raja Grafindo Persada. 1995

Ridwan . Metode dan Teknik Menyusun Tesis. Bandung: Alfabeta. 2007

Kompetensi Kepribadian, Kompetensi Sosial Guru dan Prestasi Belajar Siswa di Kabupaten Tanah Laut, Penerbit: Pustaka Banua. 2014.

Ahmad Izzan. Metodologi Pembelajaran Bahasa Arab. Humaniora, Bandung. 2007.

Tayar Yusuf, Syaiful Anwar.. Metodologi Pengajaran dan Bahasa Arab. PT. Jakarta: Grafindo.1997 